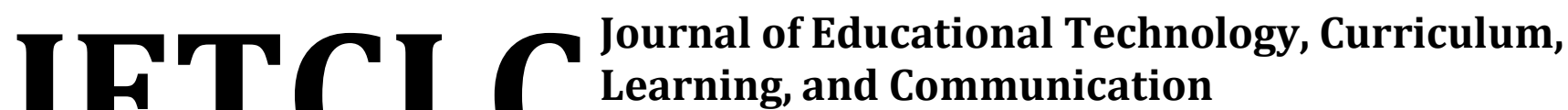 \\ Volume 1 Nomor 1 Januari 2021 Hal. 28-34 \\ ISSN: e-ISSN: 2774 - 8405
}

\section{Belajar Mandiri dan Pembelajaran Berbasis Daring di Perguruan Tinggi}

\author{
Muhammad Tahir $\mathbf{G}^{1^{*}}$, M. Darwis ${ }^{2}$ \\ ${ }^{1}$ Program Studi Teknologi Pendidikan/Fakultas Keguruan dan Ilmu Pendidikan/Universitas Pejuang RI \\ Makassar \\ Email: emtahirge@gmail.com \\ ${ }^{2}$ Program Studi Teknologi Pendidikan/Fakultas Keguruan dan Ilmu Pendidikan/Universitas Pejuang RI \\ Makassar \\ Email: darwisnurtinri@gmail.com
}

\begin{abstract}
This study aims to determine the independence of students in conducting off-campus learning activities without the physical presence of faculty but using information technology tools in different rooms and locations. The variables for independent learning and online-based learning were limited during the coronavirus pandemic (COVID-19). The secondary data needed comes from student responses to online-based learning that are linked to aspects of independent learning activities for students. The population in this study was all undergraduate students in Educational Technology, Universitas Pejuang RI. Macassar. The sample was collected using a dedicated sampling method that focused only on students enrolled in the Education Communication System course. Due to the COVID-19 pandemic, online-based learning was implemented. The data was collected through online questionnaires and in-depth interviews with several students in order to obtain more detailed information. The data analysis technique used in this study is percentage description analysis, which consists of data acquisition, data reduction, data presentation and final drawing. The results of this study show that the activities of students in online-based learning in the subject of educational communication systems show a positive correlation with learning independence, with details of the aspects being assessed. The ability to ask and answer questions about the material being taught is $(61.12 \%)$ and can provide immediate feedback on the faculty of the instructor's questions (60.14\%) on the aspect of the ability to do tasks appropriately and the content of the Material processed with references gives solid and integrated course material (50.22\%). The conclusion is behind online learning and its problems. However, positive data are obtained from the independent attitude of students to learning. This is because online learning in college can improve the ability to ask questions on the fly, provide feedback according to the originality of their thoughts, and process course materials with other supportive materials of the initiative. alone.
\end{abstract}

Keywords: Independent learning; online learning

\begin{abstract}
ABSTRAK
Penelitian ini bertujuan untuk mengetahui Kemandirian mahasiswa dalam melakukan aktifitas belajar di luar kampus tanpa kehadiran dosen secara fisik, namun menggunakan alat Teknologi Informasi dengan berada ruang dan tempat yang berbeda. Variabel kemandirian belajar dan pembelajaran berbasis daring dibatasi selama masa pandemi virus corona (COVID-19). Adapun data sekunder yang dibutuhkan adalah melalui tanggapan mahasiswa terhadap pembelajaran berbasis daring yang dikaitkan dengan aspek aktifitas belajar mandiri bagi mahasiswa. Populasi pada penelitian ini adalah seluruh mahasiswa program sarjana Program studi Teknologi Pendidikan
\end{abstract}



Universitas Pejuang RI. Makassar. Sampel diambil dengan menggunakan teknik purposive sampling yang hanya berfokus pada mahasiswa yang sedang mengambil mata kuliah Sistem Komunikasi Pendidikan diberlakukan pembelajaran berbasis daring karena pandemi COVID-19. Data dikumpulkan dengan menggunakan kuesioner secara daring dan wawancara mendalam kepada beberapa mahasiswa untuk mendapatkan informasi yang lebih mendetail. Teknik analisis data yang digunakan dalam penelitian ini adalah analisis deskripsi persentase yang terdiri atas pengumpulan data, reduksi data, penyajian data, dan penarikan kesimpulan. Hasil penelitian ini menunjukkan bahwa aktifitas mahasiswa dalam pembelajaran berbasis daring pada mata kuliah sistem komunikasi Pendidikan berkorelasi potisitif dalam kemandirian belajar, dengan rincian aspek yang dinilai; kemampuan tanya jawab yang terkait dengan materi yang diajarkan sebesar (61,12\%), serta mampu memberikan umpan balik sesaat bila ada pertanyaan dari dosen sebesar (60,14\%), pada aspek kemampuan menyelesaikan tugas dengan tepat dan isi materi yang diolah dengan rujukan materi kuliah yang padat dan terintegrasi (50,22\%). Simpulannya dibalik Pembelajaran daring dan problemnya, namun dari sikap kemandirian belajar mahasiswa diperoleh data yang positip, ini karena pembelajaran daring di perguruan tinggi dapat meningkatkan kemampuan bertanya secara spontan, memberikan umpan balik sesuai keorisionalan pikirannya, serta mampu mengolah materi kuliah dengan materi penunjang lainnya atas inisiatif sendiri.

Kata Kunci : Belajar Mandiri; Pembelajaran Daring

\section{PENDAHULUAN}

Menteri Pendidikan dan Kebudayaan (Mendikbud) Nadiem Makarim menegaskan, bencana pandemi virus corona SARS-CoV2 (Covid-19) di tanah air membuat kegiatan belajar mengajar (KBM), seminar dan ujian skripsi di kelas terpaksa ditiadakan. Dalam kondisi tertentu meski mahasiswa sekarang belajar dari rumah, bukan berarti kegiatan belajar mengajar (KBM) 100 persen dilakukan secara dalam jaringan (daring). Tam dan El Azar (2020) menyatakan pandemi virus corona menyebabkan tiga perubahan mendasar di dalam pendidikan global. Pertama, mengubah cara jutaan orang dididik. Kedua, solusi baru untuk pendidikan yang dapat membawa inovasi yang sangat dibutuhkan. Ketiga, adanya kesenjangan digital menyebabkan pergeseran baru dalam pendekatan pendidikan dan dapat memperluas kesenjangan. Informasi ini menunjukkan pembelajaran daring yang berlangsung sebagai dampak dari pandemi Covid-19, membuat seluruh komponen internal dan eskternal Pendidikan harus berbenah untuk menghadapi tantangan yang mengejutkan ini. Prinsip utama bahwa pembelajaran daring harus menjadi bagian integral dari semua kegiatan pembelajaran, dan komponen utama yang lebih dominan adalah dosen yang menyusun strategi dan menata seluruh aspek yang terkait dengan sistem pembelajaran daring.
Dengan Pemberlakuan secara serentak tentang kebijakan physical distancing yang kemudian menjadi dasar pelaksanaan kegiatan belajar dari rumah, dengan pemanfaatan alat teknologi informasi dan komunikasi yang berlaku secara simultan, sehingga para dosen harus membuat kesepakatan dengan mahasiswanya mengenai waktu dan metode yang digunakan. Selain itu, hal yang paling urgent diperhatikan adalah akses dan menjadi penentu optimalisasi pembelajaran daring. Terkait dengan ini diperjelas oleh Lembani, dkk (2019) menyebut open distance learning meningkatkan peluang bagi akses ke pendididikan karena tersedianya materi daring. Namun, kondisi tersebut sangat dipengaruhi oleh beragam variabel seperti umur, akses terhadap komputer dan internet, maupun kesenjangan digital. Memfasilitasi akses yang memadai misalnya, menjadi salah satu hal yang sangat mendasar dalam mendukung kelancaran open distance learning.

Memperhatikan perkembangan teknologi informasi dan komunikasi pada era Industri 4.0 saat ini, telah memiliki pengaruh yang besar terhadap proses pembelajaran di perguruan tinggi. Pemanfaatan teknologi telah digunakan oleh para pengajar dapat membantu proses dan hasil pembelajaran yang berkualitas. Saat ini para mahasiswa dapat belajar kapan dan dimana 
saja, tetapi sekaligus dengan fasilitas sistem electronic learning yang ada. E-learning kini semakin dikenal sebagai salah satu cara untuk mengatasi masalah Pendidikan dari kualitas, efisesien dan dan efektifitas di perguruan tinggi. Hoskins (2013) menyebut tidak mudahnya melakukan pembelajaran jarak jauh di kalangan mahasiswa. Padahal pembelajaran ini lebih mudah dilakukan pada mahasiswa, karena termasuk peserta didik yang sudah dewasa. Selain itu pembelajaran ini harus didukung oleh desain kelas dan metode penyampaian yang tepat sehingga pembelajaran daring dapat mendorong mahasiswa untuk merefleksikan kepercayaan mereka; menyediakan lingkungan yang aman untuk mendiskusikan berbagai perspektif; membimbing mereka untuk mengeksplorasi, memvalidasi, dan memperluas pandangan baru; dan mendukung mereka mengembangkan peran baru. Berubahnya peran tenaga pengajar dari yang semula menguasai teknik pembelajaran konvensional yang sudah berlangsung lama, maka kebutuhan masa kini dituntut untuk menguasai teknik pembelajaran dengan menggunakan ICT (Information Communication Technology). Resiko yang dapat ditimbulkan bila ada peserta didik yang tidak mempunyai motivasi belajar mandiri yang tinggi, dan bila hal ini terjadi pasti cenderung gagal. Tidak semua tempat tersedia fasilitas internet (berkaitan dengan masalah tersedianya listrik, telepon, dan komputer). (Taufik.net, 2010).

Penerapan Pembelajaran Berbasis Daring adalah sebuah pendekatan yang tepat dalam menyelesaikan masalah belajar individu dengan memanfaatkan jaringan internet oleh mahasiswa dalam proses pembelajaran. Pendekatan pembelajaran berbasis daring memiliki karakteristik sebagai berikut: 1) menuntut pembelajar untuk membangun dan menciptakan pengetahuan secara mandiri (constructivism); 2) pembelajar akan berkolaborasi dengan pembelajar lain dalam membangun pengetahuannya dan memecahkan masalah secara bersama-sama (social constructivism); 3) membentuk suatu komunitas pembelajar (community of learners) yang inklusif; 4) memanfaatkan media laman (website) yang bisa diakses melalui internet, pembelajaran berbasis komputer, kelas virtual, dan atau kelas digital; 5) interaktivitas, kemandirian, aksesibilitas, dan pengayaan (Ditjen GTK, 2016, p.5).
Dengan mengacu pada konten latar belakang masalah ini, maka kajian utama penelitian ini adalah focus pada kemandirian belajar dan pembelajaran berbasis daring di Perguruan Tinggi.

\section{METODE}

Penelitian ini dilakukan dengan cara memperhatikan keaktifan mahasiswa dalam proses kuliah berbasis daring. Untuk menilai kemampuan kemandirian mahasiswa dipergunakan metode tanya jawab sebelum dan sesudah perkuliahan berlangsung yang dimulai pada pertemuan pertama sampai ke enam, serta mengedarkan angket yang memuat pilihan ganda dengan empat (4) option sikap belajar mandiri melalui Whatsapp (WA). Mahasiswa yang dijadikan sampel penelitian ini diambil secara purposive sebanyak 14 orang yang memprogramkan mata kuliah sistem Komunikasi Pendidikan semester genap 2019/2020 pada program Studi Teknologi Pendidikan Universitas Pejuang Republik Indonesia Makassar. Hasil pengumpulan data, baik primer maupun data sekunder melalui jawab jawab maupun angket, kemudian dianalisis dengan Teknik Deskripsi prosentase.

\section{HASIL DAN PEMBAHASAN}

\section{Pembelajar Daring}

Pembelajaran daring (online) merupakan bagian dari pendidikan jarak jauh yang secara khusus menggabungkan teknologi elektronika dan teknologi berbasis internet. adanya keterpisahan antara pendidik dan peserta didik lintas ruang dan waktu sehingga lebih menekankan pada belajar secara mandiri. Menurut Koran (2002) E-learning sebagai sembarang pengajaran dan pembelajaran yang menggunakan rangkaian elektronik (LAN, WAN, atau internet) untuk menyampaikan isi pembelajaran, interaksi, atau bimbingan. Hartley (2001) menjelaskan bahwae E-learning merupakan suatu jenis belajar mengajar yang memungkinkan tersampaikannya bahan ajar ke siswa dengan menggunakan media internet, intranet atau media jaringan komputer lain. Rosenberg (2001) menekankan bahwa Elearningmerujuk pada penggunaan teknologi internet untuk mengirimkan serangkaian solusi yang dapat meningkatkan pengetahuan dan keterampilan. 
di Perguruan Tinggi

Berdasarkan perkembangan e-learning dari dari masa ke masa yang terus berkembang mengikuti perkembangan teknologi, maka dapat disimpulkan bahwa elearning akan menjadi sistem pemblajaran masa depan. Efektifitas dan fleksibilitas akan menjadi alasan utama. (Tiyas, 2014) .

Pembelajaran daring adalah salah satu metode pilihan dan diunggulkan untuk mengatasi dan memutus mata rantai penyebaran virus corona (covid 19) di semua bidang termasuk di perguruan tinggi. Selain misi utama penerapan metode ini terkait dengan virus corona (covid 19), juga bagimana efektifitasnya yang mampu menciptakan suasana pembelajaran yang optimal serta mengubah perilaku mahasiswa dalam aspek pemahaman materi yang diajarkan dengan kualitas yang seimbang dengan hasil pembelajaran konvensional. Seperti yang telah disampaikan oleh Keengwe \& Georgina dalam penelitiannya telah menyatakan bahwa perkembangan teknologi memberikan perubahan terhadap pelaksanaan pengajaran dan pembelajaran (Keengwe \& Georgina, 2012). Teknologi informasi dapat diterima sebagai media dalam melakukan proses pendidikan, termasuk membantu proses belajar mengajar, yang juga melibatkan pencarian referensi dan sumber informasi (Wekke \& Hamid, 2013).

Proses penyampaian materi kuliah melalui daring dapat bersifat interaktif sehingga peserta didik mampu berinteraksi dengan komputer sebagai media belajarnya. Hal ini dapat diperhatikan bila ada peserta didik yang menggunakan pembelajaran media elektronik atau menjalin hubungan (browsing, chatting, vidiocall) melalui media elektronik, dalam hal ini komputer dan internet nantinya akan memperoleh hasil belajar yang lebih efektif dan baik dari pada pembelajaran konvensional.

Pembelajaran berbasis daring dalam proses belajar mengajar merupakan salah satu upaya untuk meningkatkan efektivitas serta kualitas proses pembelajaran yang pada akhirnya dapat meningkatkan kualitas hasil belajar mahasiswa. Kuliah berbasis daring dengan memanfaatkan muliti media pembelajaran dalam proses belajar mengajar memiliki beberapa manfaat diantaranya: (1) Pengajaran akan lebih menarik perhatian mahasiswa sehingga dapat menumbuhkan motivasi belajar yang tinggi, (2)
Materi kuliah yang disampaikan oleh dosen akan lebih jelas sehingga mahasiswa dapat memahami dan menguasai tujuan pengajaran dengan baik, (3) Metode mengajar akan lebih bervariasi karena menggunakan muliti media (4) Mahasiswa akan lebih banyak melakukan interaksi dalam kegiatan belajar terhadap lingkungan sekitarnya atas inisiatif sendiri.

Sistem pembelajatan berbasis daring telah mempersingkat waktu pembelajaran dan membuat biaya studi lebih ekonomis dan praktis. Pembelajaran online mempermudah interaksi antara peserta didik dengan bahan atau materi pelajaran, mahasiswa dengan dosen maupun sesama mahasiswa. Mahasiswa dapat saling berbagi informasi dan dapat mengakses bahan - bahan belajar setiap saat dan berulang ulang, dengan kondisi yang demikian itu mahasiswa dapat lebih memantapkan penguasaannya terhadap materi pembelajaran.

\section{Proses Belajar Mandiri}

Sikap belajar mandiri merupakan wujud harapan setiap dosen, karena salah satu indicator tingkat kesuksesan dalam proses daring. Walaupun ini sulit dinilai secara objektif bagi dosen terhadap perilaku mahasiswa baik pada saat berlangsung kegiatan perkuliahan maupun sesudahnya. Dengan kondisi pembelajaran daring dimana pembelajaran berlangsung dengan pemisah (ada jarak) ruang yang berbeda, sehingga focus mahasiswa terhadap materi yang dikaji bisa tidak maksimal, bila dosen tidak mampu menggunakan siasat yang menciptakan suasana pembelajaran dengan interaksi yang optimal, baik antara dosen dengan mahasiswa dan selanjutnya antar mahasiswa.

Sikap belajar mandiri bagi mahasiswa dapat tercipta, ketika pembelajaran berbasis daring dapat menimbulkan ransangan bagi mahasiswa untuk mempelajari dan mengkaji ulang materi kuliah yang disampaikan oleh dosen. Dalam proses belajar mandiri didasari perilaku inisiatif sendiri yang diwujudkan dalam kegiatan antara lain; mencari informasi terkait dengan perkuliahan, mengidentifikasi materi kuliah, berupaya mencari alternatif pemecahan masalah bila ada kesulitan dalam memahari materi.

Melalui pembelajaran berbasis daring dapat memberikan keluasaan kepada mahasiswa untuk mengatur waktu belajar. Mahasiswa dapat belajar tidak terikat oleh waktu, kapanpun dan 
di manapun. Bahkan mahasiswa dapat berinteraksi dengan dosen baik secara synchronous, yakni interaksi belajar pada waktu yang bersamaan seperti dengan menggunakan video converence, telepon atau live chat, maupun asynchronous, yakni interaksi belajar pada waktu yang tidak bersamaan melalui kegiatan pembelajaran yang telah disediakan secara elektronik.

Dengan pemanfaatan informasi dan teknologi, mahasiswa secara maksimal dapat melaksanakan pembelajaran berbasis daring dengan cara mengakses dan mempelajari bahan perkuliahan, mengerjakan latihan-latihan (tugas), berdiskusi dan berbagi ilmu pengetahuan dan pengalaman dengan mahasiswa pembelajar lainnya. Selama proses pembelajaran, mahasiswa dapat dibimbing dan difasilitasi secara online oleh dosen. Agar dalam pelaksanaan pembelajaran berbasis daring berjalan lancar dan maksimal maka dosen harus mempersiapkan modul pembelajaran. Modul yang disusun oleh dosen harus memenuhi dua syarat yaitu pertama, mempunyai rumusan tujuan pembelajaran yang jelas, spesifik, teramati, dan terukur untuk mengubah perilaku pembelajar. Dan kedua, konten dalam modul harus relevan dengan kebutuhan mahasiswa sebagai sumber belajar.

Partisipasi mahasiswa dalam kegiatan Pembelajaran berbasis daring ini sangat penting karena dapat mengembangkan keterampilan instruksional dan pengetahuan terhadap konten pembelajaran yang bersangkutan. Melalui sumber belajar dalam berbagai bentuk dan referensi yang tersedia di sistem pembelajaran berbasis daring, peserta dapat mengikuti pembelajaran untuk meningkatkan pengetahuan dan keterampilan terkait dengan materi pembelajaran yang di sajikan. Ada beberapa prinsip yang menjadi landasan dalam pelaksanaan pembelajaran berbasis daring yaitu sebagai berikut: a) rumusan tujuan pembelajaran pada setiap modul telah jelas, spesifik, teramati, dan terukur untuk mengubah perilaku pembelajar; b) konten di modul telah relevan dengan kebutuhan pembelajar, masyarakat, dunia kerja, atau dunia pendidikan; c) meningkatkan mutu pendidikan yang ditandai dengan pembelajaran lebih aktif dan mutu lulusan yang lebih produktif; d) efisiensi biaya, tenaga, sumber dan waktu, serta efektivitas program; e) pemerataan dan perluasan kesempatan belajar; f) pembelajaran yang berkesinambungan dan terus menerus (Ditjen GTK, 2016, p.8).

Belajar Mandiri Dalam Berbagai Program Pembelajaran, menurut Wedemeyer dan Moore (dalam Keegan, 1983), kemandirian belajar itu dapat ditinjau dari ada tidaknya kesempatan yang diberikan kepada peserta didik (1) dalam menentukan tujuan pembelajaran, (2) dalam memilih cara dan media belajar yang digunakan untuk mencapai tujuan, dan (3) dalam menentukan cara, alat, dan kriteria evaluasi hasil belajarnya. Kemandirian belajar diberikan kepada mahasiswa dengan maksud supaya mempunyai tanggung jawab untuk mengatur dan mendisiplinkan dirinya dan mengembangkan kemampuan belajar atas kemauan sendiri. Sikap-sikap tersebut perlu dimiliki mahasiswa karena hal tersebut merupakan ciri kedewasaan orang yang terpelajar.

Kemandirian belajar tidak akan muncul secara otomatis tetapi harus ada faktor yang menunjangnya. Benson (dalam Mauly Halwat Hikmat, 2006) mengemukakan pendapatnya tentang prinsip- prinsip meningkatkan kemandirian belajar adalah: (1) melibatkan peserta didik secara aktif, (2) memberikan pilihan pembelajaran dan sumber belajar, (3) memberi kesempatan untuk memilih dan memutuskan, memberi semangat kepada peserta didik, (5) mendorong peserta didik untuk melakukan refleksi. Haris Mujiman (2011) merumuskan belajar mandiri adalah kegiatan belajar aktif yang didorong oleh motif untuk menguasai suatu kompetensi guna mengatasi masalah dan dibangun dengan bekal pengetahuan atau kompetensi yang dimiliki. Pengembangan keterampilan belajar mandiri dapat dilakukan dengan dua cara, yaitu dosen membekali mahasiswa dengan strategi kognitif dan dosen membimbing mahasiswa melalui kontrak perkuliahan. Dalam hal ini, yang perlu dipertimbangkan adalah tujuan proses belajar mandiri dari suatu mata kuliah apakah untuk pencapaian keterampilan atau pengetahuan tertentu ataukah untuk pengembangan kebiasaan dan kemampuan belajar mandiri.

Indikator Kemandirian Belajar mahasiswa dapat dilihat dari siapa yang mengambil 
inisiatif untuk menentukan apa yang harus dipelajari, bagaimana mempelajarinya dan mengukur keberhasilannya. Menurut Paulina Pannen (2001) ciri utama belajar mandiri: (1) pengembangan dan peningkatan keterampilan dan kemampuan mahasiswa untuk melakukan proses belajar secara mandiri tidak tergantung pada faktor-faktor dosen, kelas, teman, dan lain- lain, (2) peran utama dosen dalam belajar mandiri adalah sebagai konsultan dan fasilitator, bukan sebagai otoritas dan satusatunya sumber ilmu. (3) Menurut Murray Fisher (2001), kemandirian belajar dapat dicermati dari tiga aspek yaitu: pengelolaan diri, keinginan untuk belajar dan pengendalian diri (4) Pengelolaan diri meliputi pengelolaan waktu, kedisiplinan, percaya diri.

Dalam mengelola waktu, mahasiswa harus dapat membedakan mana aktivitas yang penting dan mana yang mendesak. Kegiatan dikatakan penting adalah kegiatan yang berhubungan dengan hasil-hasil yang diharapkan. Segala sesuatu yang berhubungan dengan sasaran prioritas tinggi adalah penting. Sementara kegiatan yang mendesak adalah kegiatan yang memerlukan tindakan segera saat ini juga. Cara belajar mandiri menghendaki mahasiswa untuk belajar atas prakarsa atau inisiatif sendiri. Belajar mandiri dapat dilakukan secara sendiri ataupun berkelompok, baik dalam kelompok belajar maupun dalam kelompok tutorial. Setiap Dosen atau perguruan tinggi hndaknya menyediakan bahan ajar yang dirancang untuk dapat dipelajari secara mandiri bagi mahasiswa. Selain itu mahasiswa juga dapat mengambil inisiatif untuk memanfaatkan bahan bacaan lain sebagai bentuk kegiatan mandiri seperti bahan materi tambahan diperpustakaan. Intinya kegiatan belajar mandiri yang dapat diwujudkan baik secara tatap muka maupun melalui internet, radio, dan televisi; serta memanfaatkan sumber belajar lain seperti bahan ajar berbantuan komputer dan program audio/video.

Belajar mandiri dalam banyak hal ditentukan oleh kemampuan belajar secara efektif. Kemampuan belajar bergantung pada kecepatan membaca dan kemampuan memahami isi bacaan yang disampaikan oleh dosen. Untuk dapat belajar mandiri secara efektif, mahasiswa dituntut memiliki disiplin diri, inisiatif, dan motivasi belajar yang kuat. Bahkan Mahasiswa juga dituntut untuk dapat mengatur waktunya dengan efisien, sehingga dapat belajar secara teratur berdasarkan jadwal belajar yang ditentukan sendiri. Oleh karena itu, agar dapat berhasil belajar secara maksimal, maka para mahasiswa harus siap untuk belajar secara mandiri dengan mengikuti petunjuk masing-masing dosen yang umumnya disampaikan pada awal pertemuan.

\section{SIMPULAN DAN SARAN}

Munculnya wabah virus corona (covid) 19 yang bermula pada bulan Desember 2019, yang mempengaruhi terhadap berbagai aktifitas keseharian, termasuk dalam bidang Pendidikan di Perguruan Tinggi. Karena penyebaran virus ini harus dihindari dan diputus mata rantainya, maka metode pembelajaran di perguruan tinggi yang sedang berlangsung secara konvensional pada pertengahan semester genap 2019/2020, harus diubah dengan menerapkan pembelajaran berbasis daring.

Penerapan metode daring dalam pembelajaran di perguruan tinggi berkorelasi positif terhadap sikap belajar mandiri mahasiswa, hal ini diperoleh wujud sikap kemandirian belajar mahasiswa mulai pada saat tanya jawab yang terkait dengan materi yang diajarkan sebesar $(61,12 \%)$, serta mampu memberikan umpan balik sesaat bila ada pertanyaan dari dosen sebesar $(60,14 \%)$, pada aspek kemampuan menyelesaikan tugas dengan tepat dan isi materi yang diolah dengan rujukan materi kuliah yang padat dan terintegrasi $(50,22 \%)$.

Keterbatasan bertemu dan berkonsultasi dengan dosen, baik dalam menyampaikan materi perkuliahan yang tidak bisa dijamin sepenuhnya diterima secara maksimal oleh mahasiswa, yang disebabkan karena selain perubahan metode mengajar secara tiba-tiba juga ketersediaan sarana dan jaringan internet yang sering terganggu. Maka idealnya mahasiswa tidak sepenuhnya mengharapkan sumber belajar satusatunya dari dosen, melainkan mahasiswa harus bersikap mengambil inisiatif sendiri mencari materi pendukung serta mengembangkan sesuai kemampuan individu mahasiswa.

Perlu diingat juga bahwa sehebat apapun kemajuan teknologi pembelajaran tentu mempunyai kelebihan dan kekurangan, sehingga pembelajaran konvensional tetap diperlukan, hal 
ini sangat mendasarkan karena sifat materi yang dibutuhkan para mahasiswa sangat bervariasi. Dengan demikian kemajuan teknologi pembelajaran tidak bisa menggeser sepenuh system pembelajaran tatap muka, karena kedua metode ini saling melengkapi.

\section{DAFTAR RUJUKAN}

Miarso,Y. (2005). Menyemai benih teknologi pendidikan. Jakarta: Kencana.

Taufik.net. (2010). Kelebihan Dan Kekurangan. $1-7$.

Tiyas, N. R. (2014). Sejarah E-Learning.

Setiawan, P. (2020). Pengertian E-learning Pengertian E-learning Menurut Para Ahli Karakteristik E-learning Manfaat E-learning.

Barbara J. Hoskins.2013.Is Distance Learning Transformational?.The Journal of Continuing Higher Education,61:1,6263,DOI: 10.1080/07377363.2013.7594 88.

Ditjen GTK, Kemendikbud. Jakarta, 2016, p.8).

Luthra, Poornima \& Mackenzie, Sandy. 2020. 4 Ways Covid-19 Education Future Generations. Sumber: https://www.wef orum.org/agenda/2020/03/4-wayscovid-19-education-future-generations/.

Reuben Lembani, Ashley Gunter, Markus Breines \& Mwazvita Tapiwa Beatrice Dalu. 2020.The same course, different access: the digital divide between urban and rural distance education students in South Africa.Journal of Geography in Higher Education, 44:1,7084,DOI: $10.1080 / 03098265.2019 .1694$ 876.

Tam, Gloria \& El-Azar, Diana. 2020. 3 ways the coronavirus pandemic could reshape education.Sumber: https://www.weforu m.org/agenda/2020/03/3-wayscoronavirus-is-reshaping-education-andwhat-changes-might-be-here-to-stay/.

Zhong, Raymond. 2020. The Coronavirus Exposes Education's Digital Divide. Sumber: https://www.nytimes.com/2020 103/17/technology/china-schoolscoronavirus.html. 